\title{
Pengaruh Kepemilikan Institusioanal, Kepemilikan Manajemen, Kebijakana Deviden, Perilaku Oportunistik dan Profitabilitas Terhadap Nilai Perusahaan
}

\author{
Eva Agustiany $\mathbf{P}$ \\ Correspondence Author: evaagustiany.p@gmail.com \\ Fakultas Bisnis dan Ekonomika, Universitas Islam Indonesia, Indonesia
}

INDEXING

Keywords:

Institutional

ownership;

Managerial

ownership;

dividend policy,

opportunistic

behavior;

profitability;

Kata kunci:

Kepemilikan institusional,

Kepemilikan

manajerial;

kebijakan dividen,

perilaku

opportunistic;

profitabilitas;

\begin{abstract}
This study aims to analyze the influence of institutional ownership, management ownership, dividend policy, opportunistic behavior and profitability on firm value. Firm value is also the price of a share on the stock market that investors are willing to pay to own a company. The population in this study were all banking companies listed on the Indonesia Stock Exchange during the 2014-2018 period, totaling 31 companies. Sampling was done by using purposive sampling. The sample of this research is banking companies that have reported financial reports during the 2016-2018 period using a website, namely $w w w . i d x . i d$. The data collection method is done by using data documentation techniques which are historical data available in the form of reports. The data analysis technique used in this study is the Panel regression analysis technique. The results of this research hypothesis testing indicate that institutional ownership and profitability have a significant positive effect on firm value. Meanwhile, dividend policy has a significant negative effect on firm value. Another result found that managerial ownership and opportunistic behavior had no significant positive effect on firm value.
\end{abstract}

\begin{abstract}
ABSTRAK
Penelitian ini bertujuan untuk menganalisis pengaruh pengaruh kepemilikan institusioanal,kepemilikan manajemen, kebijakana deviden, perilaku oportunistik dan profitabilitas terhadap nilai perusahaan.Nilai perusahaan juga merupakan harga sebuah saham pada pasar saham yang bersedia dibayar oleh investor untuk memiliki sebuah perusahaan. Populasi dalam penelitian ini adalah seluruh perusahaan perbankan yang terdaftar di Bursa Efek Indonesia selama periode 2014-2018 yang berjumlah 31 perusahaan. Pengambilan sampel dilakukan dengan Purpose Sampling. Sampel penelitian ini adalah perusahaan perbankan yang sudah melaporkan laporan keuangan selama periode 2016-2018 menggunakan website yaitu www.idx.id. Metode pengumpulan data dilakukan dengan teknik dokumentasi data yang digunakan merupakan data historis yang tersedia dalam bentuk laporan. Teknik analisis data yang digunakan dalam penelitian ini adalah teknik analisis regresi Panel. Hasil pengujian hipotesis penelitian ini menunjukkan bahwa Kepemilikan institusional dan profitabilitas berpengaruh positif secara signifikan terhadap nilai perusahaan. Sementara Kebijakan dividen berpengaruh negatif secara signifikan terhadap nilai perusahaan. Hasil yang lain menemukan bahwa Kepemilikan manajerial dan Perilaku oportunistik tidak berpengaruh positif secara signifikan terhadap nilai perusahaan.
\end{abstract}

ARTICLE HISTORY

Received: 2020-06-17 Revised: 2020-08-19 Accepted: 2020-08-31

\section{PENDAHULUAN}

Pada umumnya, suatu perusahaan didirikan dengan tujuan meningkatkan nilai perusahaan tersebut secara maksimal. Nilai perusahaan dicerminkan dari harga saham suatu perusahaan. Selain itu tujuan didirikannya perusahaan adalah untuk mencapai keuntungan yang maksimal dan untuk meningkatkan kesejahteraan para pemilik perusahaan dan pemegang saham. Optimalisasi nilai perusahaan dapat dicapai melalui pelaksanaan kinerja keuangan yang baik. Pengambilan keputusan dalam suatu perusahaan dapat berdampak dengan keputusan keuangan yang lainnya sehingga memberikan dampak yang positif atau 
bahkan negatif pada nilai perusahaan itu semua tergantung keputusan keuangan yang seperti apa yang diterapkan (Hidayah,2015).

Masalah keagenan (agency problem) dapat terjadi dalam kaitannya terhadap pengambilan keputusan-keputusan keuangan perusahaan agar sesuai dengan tujuan perusahaan. Terlebih ketika menghadapi kondisi ekonomi yang tidak stabil akibat krisis global yang terjadi. Pengambilan keputusan-keputusan keuangan yang tepat berdasarkan sudut pandang pemegang saham, manajer dan kreditor akan sangat berpengaruh terhadap kelangsungan perusahaan dan pencapaian tujuanperusahaan. Keputusan-keputusan keuangan tersebut mencakup keputusan investasi, keputusan pendanaan, dan kebijakan dividen.

Konsep yang dapat mencegah atau mengurangi kecenderungan dari para manajer korporasi untuk berperilaku opportunistik yaitu dengan adanya struktur kepemilikan dan mekanisme corporate governance, salah satu bagian dari mekanisme corporate governance yaitu dengan adanya kepemilikan manajerial dan institusional telah disarankan sebagai salah satu mekanisme yang membantu menyelaraskan kepentingan manajer dengan kepentingan para pemegang saham. Ini karena manajer yang memiliki ekuitas di perusahaan akan bertindak sebagai pemilik dan mengurangi tingkat penyitaan dari investor luar (Jensen dan Meckling, 1976). Dalam upaya memaksimalkan kesejahteraan mereka sendiri, manajer mungkin tergoda untuk membangun kerajaan, mengumpulkan manfaat pribadi, melakukan proyek investasi khusus manajer dan mengakar sendiri, biasanya dengan mengorbankan pemegang saham (Florackis,dkk.,2015)

Semakin tinggi kepemilikan institusional akan mendorong investor institusional untuk melakukan pengawasan bisnis yang lebih baik. Sehingga perilaku oportunistik manajer dapat dicegah. Sejalan dengan pendapat diungkapkan oleh (Xiong, 2016) yang mengatakan bahwa kepemilikan institusional (INST) dapat meningkatkan nilai perusahaan melalui partisipasi dalam tata kelola perusahaan dan mengawasi kegiatan perusahaan sehingga itu akan meningkatkan nilai perusahaan. Karena situasi ini, masalah keagenan muncul antara pemegang saham dan manajer dapat diminimalkan.

Bagian hak kepemilikan saham manajerial ini diberikan oleh pemegang saham dengan harapan bahwa para pengelola perusahaan dapat lebih memiliki sense of belonging sehingga loyalitas, dedikasi, dan produktivitasnya bisa lebih meningkat terhadap perusahaan. Yang pada akhirnya mencapai tujuan perusahaan yaitu memaksimumkan keuntungan bagi pemegang saham. Memaksimumkan nilai perusahaan sama dengan memaksimumkan harga pasar saham. Memaksimumkan harga saham tidak sama dengan memaksimumkan keuntungan (profit) perusahaan. Bagi manajer, tujuan memaksimumkan keuntungan akan mendorong manajemen perusahaan memilih proyek-proyek yang menjanjikan keuntungan besar. Sedangkan untuk menanamkan modalnya, investor melihat nilai perusahaan melalui harga saham. Morck dkk.,1988) menemukan signifikan positif hubungan antara nilai perusahaan dan kepemilikan ketika kepemilikan dewan antara 0 dan 5 persen dan hubungan negatif yang signifikan ketika kepemilikan dewan berada di Kisaran 5-25 persen.

Pembagian dividen yang dilakukan oleh perusahaan dapat menjadi indikasi bahwa perusahaan dapat memaksimumkan kemakmuran para pemegang saham, pembayaran dividen juga diharapkan dapat menjadi pertimbangan investor terhadap kinerja perusahaan dikarenakan tinggi maupun rendahnya dividen yang dibayarkan oleh perusahaan dapat mempengaruhi harga saham. karena banyaknya jumlah deviden yang dibagikan ke 
pemegang saham akan mempengaruhi harga saham perusahaan tersebut. Apabila jumlah deviden yang dibagikan besar, maka harga saham perusahaan tersebut cenderung naik sehingga dengan harga saham yang tinggi akan diikuti dengan nilai perusahaan yang tinggi, sebaliknya jika deviden yang dibagikan ke pemegang saham jumlahnya sedikit maka akan membuat harga saham perusahaan tersebut menurun yang menyebabkan penurunan pada nilai perusahaan. Pembayaran dividen kepada pemegang saham memiliki hubungan yang erat dengan kemampuan perusahaan dalam memperoleh laba. Karena dengan memperoleh laba yang tinggai maka perusahaan dalam membagikan deviden kepada pemegang saham juga tinggi(Martono dan Harjito 2012).

Faktor lain yang mempengaruhi nilai perusahaan ada perilaku oportunistik. Resiko yang diproksikan dalam penelitian ini merupakan akibat dari tindakan perilaku oportunistik. Resiko pasar ini sebagai akibat dari perilaku oportunistik yang ditimbulkan dari manajer, contohnya keputusan investasi manajer mendanai proyek-proyek yang mungkin berisiko tinggi atau tidak menguntungkan, maka resiko perusahaan akan naik,dimana dalam hal ini dapat meningkatkan resiko pasar, maka resiko pasar ini peneliti jadikan ukuran sebagai proksi dari perilaku oportunistik sebagai akibat manajer melakukan tindakan yang memberikan kerugian bagi para pemegang saham yaitu manajer lebih mementingkan kepentingan pribadinya dibandingkan kepentingan pemegang saham dan tujuan dari perusahaan.

Begitu juga dengan profitabilitas perusahaan, yang diduga kuat merupakan variabel yang mempengaruhi nilai perusahaan. Profitabilitas itu sendiri merupakan kemampuan perusahaan dalam menghasilkan laba (Hanafi,2014), perusahaan yang memperoleh laba tinggi merupakan perusahaan yang banyak dicari dan diminati oleh investor dikarenakan perusahaan yang memperoleh laba yang tinggi dinilai oleh investor memiliki prospek yang baik dimasa yang akan datang dan memberikan indikasi kemampuan perusahaan dalam pengelolaan perusahaan, sehingga dapat memicu investor untuk membeli saham perusahaan dan saham perusahaan menjadi meningkat. Permintaan saham yang meningkat akan menyebabkan harga saham perusahaan yang meningkat juga.

Peneliti tertarik untuk melakukan penelitian tentang pengaruh kepemilikan manajemen, kebijakan deviden, keputusan invastasi, perilaku oportunistik dan profitabilitas terhadap nilai perusahaan, karena masih adanya gap penelitian yang menemukan hasil yang belum konsisten diantaranya Vintila \& Gherghina, 2015), (Sualehkhattak \& Hussain, 2017), (Ghalandari, 2013) dan (Yuliyanti, 2014) yang berbeda temuan (Isshaq dkk., 2009) dan (Sugiarto, 2011) tentang pengaruh kepemilikian institusional terhadap nilai perusahaan. Penelitian Mardiyati dkk, 2011) Handriani dan Robiyanto (2018) berbeda dengan penelitian Herawati (2013) dan Sukirni (2012) tentang pengaruh kebijakan dividen terhadap nilai perusahaan. Begitu juga dengan temuan Kurniaty,dkk (2018) berbeda dengan temuan Juhandi (2013)tentang masalah hubungan kepemilikan manajerial dengan nilai perusahaan, serta penelitian Nurhayati (2013) yang bertentangan dengan penelitian Herawati, (2013) tentang hubungan profitabilitas terhadap nilai perusahaan. Selain itu perbedaan penelitian ini dengan penelitian sebelumnya adalah dengan menambahkan Perilaku oportunistik sebagai salah satu variabel independen yang masih jarang diteliti.

Berdasarkan fenomena tersebut maka rumusan masalah dalam penelitian ini adalah apakah kepemilikan institusioanal,kepemilikan manajemen, kebijakana deviden,perilaku oportunistik dan profitabilitas berpengaruh terhadap nilai perusahaan. 


\section{TINJAUAN PUSTAKA}

Nilai perusahaan merupakan suatu kondisi yang telah dicapai oleh suatu perusahaan sebagai suatu gambaran dari kepercayaan masyarakat terhadap perusahaan dan nilai perusahaan merupakan nilai pasar atas surat berharga perusahaan yang beredar. Nilai perusahaan juga merupakan harga sebuah saham pada pasar saham yang bersedia dibayar oleh investor untuk memiliki sebuah perusahaan.(Azhari dan Ruzikna ,2018). Nilai perusahaan penting untuk diketahui oleh pihak internal perusahaan maupun pihak eksternal perusahaan. Menurut Hidayah (2015) nilai perusahaan merupakan hal yang sangat penting diperhatikan oleh investor. Pihak internal perusahaan melihat nilai perusahaan yang tinggi dapat dijadikan indikator kemakmuran pemegang saham, sedangkan bagi pihak eksternal nilai perusahaan dapat memberikan persepsi investor terhadap tingkat keberhasilan perusahaan yang biasanya dikaitkan dengan harga saham. nilai perusahaan tercermin pada kekuatan tawar menawar saham apabila perusahaan tersebut mempunyai prospek yang bagus dimasa yang akan datang maka harga saham akan menjadi tinggi sebaliknya perusahaan yang dinilai kurang memiliki prospek yang bagus dimasa yang akan datang maka harga saham perusahaan menjadi rendah. Nilai perusahaan yang tinggi akan membuat pasar percaya bahwa kinerja perusahaan dan prospek perusahaan dimasa yang akan datang dalam keadaan yang baik.

PBV (Price Book Value) merupakan rasio untuk mengukur sebuah perusahaan yang terus tumbuh dengan nilai yang diberikan pasar keuangan kepada manajemen dan organisasi perusahaan. Price Book Value yaitu rasio yang menggambarkan seberapa pasar menghargai nilai buku saham suatu perusahaan (Hani,2015). PBV dapat dihitung dengan seberapa besar perbandingan antara besar harga saham dengan nilai buku per lembar, dimana nilai buku per lembar saham menunjukkan aktiva bersih serta ada asumsi aktiva bersih sama dengan total ekuitas pemegang saham, dan untuk perusahaan yang berjalan dengan baik pada umumnya rasio ini mencapai diatas satu, yang akan menunjukkan bahwa nilai pasar saham lebih besar dari nilai bukunya. Semakin besar rasio PBV semakin tinggi perusahaan dinilai oleh para investor relatif dibandingkan dengan dana yang telah ditanamkan di perusahaan.

\section{Faktor yang mempengaruhi Nilai perusahaan}

\section{Pengaruh Kepemilikan Institusional terhadap nilai perusahaan}

Kepemilikan institusional merupakan kepemilikan saham perusahaan yang dimiliki oleh institusi atau lembaga seperti perusahaan asuransi, bank, perusahaan investasi dan kepemilikaan lain. Kepemilikan institusional mempunyai makna penting untuk memonitor manajemen sebab dengan adanya kepemilikan oleh institusional dapat mendorong peningkatan pengawasan yang lebih optimal. Monitoring tersebut merupakan tentu dapat menjamin kemakmuran untuk pemegang saham kepemilikan institusional yang dimana sebagai agen pengawas untuk ditekan melalui investasi yang lumayan besar di pasar modal.kepemilikan saham oleh investor institusional dapat secara signifikan meningkatkan nilai perusahaan karena investor institusional akan aktif berpartisipasi dalam pengawasan dan pengelolaan operasi bisnis harian perusahaan, untuk mengendalikan perilaku agen operator dan mengurangi risiko masalah agen. Semakin tinggi proporsi kepemilikan saham investor institusional, semakin dekat hubungannya antara nilai perusahaan (Xiong, 2016) Semakin besar kepemilikan institusional maka semakin efisien pemanfaatan aktiva perusahaan dan diharapkan juga dapat bertindak sebagai pencegahan terhadap pemborosan 
dan manipulasi laba yang dilakukan oleh manajemen sehingga akan meningkatkan nilai perusahaan. Permanasari (2010) menyatakan bahwa tingginya kepemilikan institusi akan meningkatkan pengawasan terhadap perusahaan. Pengawasan yang tinggi ini kemungkinan akan meminimalisasi tingkat penyelewengan-penyelewengan yang dilakukan oleh pihak manajer.Hal ini didukung oleh penelitian Sualehkhattak dan Hussain ( 2017), Xiong (2016),Tandean dan Winnie (2016) , (Kurniaty dkk.,2018) yang menyatakan bahwa kepemilikan institusional berpengaruh positif terhadap nilai perusahaan Sehingga hipotesis pada penelitian ini adalah :

H1 : Kepemilikan Institusional berpengaruh Positif terhadap Nilai Perusahaan.

\section{Pengaruh kepemilikan manajemen terhadap nilai perusahaan}

Menurut Jensen dan Meckling mekanisme untuk mengatasi konflik keagenan antara lain dengan meningkatkan kepemilikan insider (insider ownership), sehingga dapat mensejajarkan kepentingan pemilik dengan manajer. Semakin bertambahnya saham yang dimiliki manajer, melalui kepemilikan manajerial akan memotivasi kinerja manajemen karena mereka merasa memiliki andil dalam perusahaan baik sebagai pengambil keputusan maupun dalam tanggung jawab atas setiap keputusan yng diambil. Manajer yang terlibat sekaligus sebagai pemegang saham dapat meningkatkan nilai perusahaan karena dengan adanya kepemilikan manajemen dalam suatu perusahaan merupakan salah satu cara yang dapat mengurangi perilaku oportunistik, karena apabila seorang manajer terlibat dalam kepemilikan saham perusahaan maka manajer akan dapat memaksimalkan keuntungan pemegang saham maupun memaksimalkan keuntungan perusahaan sehingga dapat memberikan sinyal baik bagi perusahaan bahkan dapat memberikan dampak positif bagi perusahaan yaitu dengan meningkatkan nilai perusahaan.Hal ini didukung oleh penelitian (Kurniaty dkk., 2018), (Tariq dkk .,2019), yang menyatakan bahwa kepemilikan manajerial berpengaruh positif terhadap nilai perusahaanSehingga hipotesis pada penelitian ini adalah : H2 : Kepemilikan Manajemen berpengaruh Positif terhadap Nilai Perusahaan.

\section{Pengaruh kebijakan deviden terhadap nilai perusahaan}

Kebijakan dividen merupakan kebijakan perusahaan dalam membagikan keuntungan perusahaan dalam bentuk dividen maupun laba ditahan kepada para pemegang saham. Berdasarkan teori bird in the hand menyatakan bahwa investor lebih menyukai laba yang didapatkan perusahaan dibagikan dalam bentuk dividen dibandingkan dengan laba ditahan dikarenakan pembagian dividen dapat mengurangi ketidakpastian dan mengurangi resiko, dan berdasarkan teori signal kenaikan pembayaran dividen merupakan sinyal yang diberikan oleh perusahaan bagi investor bahwa prospek perusahaan yang akan datang akan semakin baik, dividen yang dibagikan kepada investor merupakan salah satu indikator bahwa perusahaan memiliki kesempatan untuk tumbuh dimasa yang akan datang,sehingga investor tertarik dengan membeli saham perusahaan, kenaikan permintaan saham yang tinggi akan membuat harga saham juga tinggi dengan harga saham yang tinggi dapat meningkatkan nilai perusahaan. . Hal ini didukung oleh penelitian Nguyen dan Bui (2019), (Mardiyati dkk.,2012) dan Fajaria (2015) menyatakan bahwa kebijakan dividen berpengaruh positif terhadap nilai perusahaan. Sehingga hipotesis pada penelitian ini adalah :

H3: Kebijakan pembayaran dividen berpengaruh positif terhadap nilai perusahaan 


\section{Pengaruh perilaku oportunistik terhadap nilai perusahaan}

Opportunistic Behavior adalah manajer melakukan tindakan yang hanya menguntungkan dirinya sendiri, namun tidak menguntungkan atau tidak memberikan manfaat bagi pemegang saham atau pemilik perusahaan, melainkan hanya untuk kesejahteraan manajer itu sendiri. Menurut Wibowo (2013), opportunistic behavior didefinisikan sebagai mencari kepentingan pribadi atau diri sendiri dengan menggunakan tipu daya (tipu muslihat). Managerial opportunism hypothesis sebagaimana diungkapkan oleh Jensen (1986) menyatakan bahwa para manajer mempunyai kecenderungan menahan kas dalam perusahaan, yang menyediakan mereka untuk mengkonsumsi lebih banyak penghasilan tambahan, menggunakan dalam membangun kerajaan, dan menginvestasikan dalam proyek-proyek dan pendapatan yang mungkin meningkatkan gengsi pribadi mereka tetapi tidak bermanfaat bagi para pemegang saham.

Resiko yang diproksikan dalam penelitian ini merupakan akibat dari tindakan perilaku oportunistik. Resiko pasar ini sebagai akibat dari perilaku oportunistik yang ditimbulkan dari manajer, contohnya keputusan investasi manajer mendanai proyek-proyek yang mungkin berisiko tinggi atau tidak menguntungkan, maka resiko perusahaan akan naik,dimana dalam hal ini dapat meningkatkan resiko pasar, maka resiko pasar ini peneliti jadikan ukuran sebagai proksi dari perilaku oportunistik sebagai akibat manajer melakukan tindakan yang memberikan kerugian bagi para pemegang saham yaitu manajer lebih mementingkan kepentingan pribadinya dibandingkan kepentingan pemegang saham dan tujuan dari perusahaan.Dengan demikian perilaku oportunistik manajerial tidak menciptakan atau meningkatkan nilai perusahaan, tetapi sebaliknya akan merusak atau menurunkan nilai perusahaan.

Jensen dan Meckling (1976), perusahaan merupakan suatu subjek terhadap meningkatnya konflik. Hal ini disebabkan karena adanya penyebaran pengambilan keputusan dan risiko yang ditanggung oleh perusahaan. Dalam konteks ini para manajer mempunyai kecenderungan untuk menggunakan kelebihan keuntungan untuk konsumsi dan perilaku oportunistik yang lain, karena mereka menerima manfaat yang penuh dari kegiatan tersebut tetapi kurang mau untuk menanggung risiko dari biaya yang dikeluarkannya. Jensen dan Meckling (1976) menyatakan hal tersebut sebagai agency cost of equity. Disamping itu manajer juga mempunyai kecenderungan untuk menggunakan hutang yang tinggi bukan atas dasar maksimalisasi nilai perusahaan, melainkan untuk kepentingan oportunistik mereka. Hal ini akan mengakibatkan beban bunga pinjaman dan risiko kebangkrutan perusahaan meningkat, karena agency cost of debt semakin tinggi. Meningkatnya biaya keagenan tersebut pada akhirnya akan berpengaruh pada penurunan nilai perusahaan. Hal ini didukung oleh penelitianGiriati (2016), menyatakan bahwa opportunistic behavior (perilaku oportunistik manajerial) memiliki pengaruh terhadap nilai perusahaandan penelitian Mai (2010) dan Nuraeni (2012) dalam studinya menggunakan risiko sistematik (BETA) dimana resiko pasar berpengaruh negatif terhadap nilai perusahaan. Sehingga hipotesis pada penelitian ini adalah :

H4: perilaku oportunistik berpengaruh negatif terhadap nilai perusahaan.

\section{Pengaruh profitabilitas terhadap nilai perusahaan}

Profitabilitas itu sendiri merupakan kemampuan perusahaan dalam menghasilkan laba (Hanafi dkk.,2014), perusahaan yang memperoleh laba tinggi merupakan perusahaan yang banyak dicari dan diminati oleh investor dikarenakan perusahaan yang memperoleh laba 
yang tinggi dinilai oleh investor memiliki prospek yang baik dimasa yang akan datang dan memberikan indikasi kemampuan perusahaan dalam pengelolaan perusahaan, sehingga dapat memicu investor untuk membeli saham perusahaan dan saham perusahaan menjadi meningkat. Permintaan saham yang meningkat akan menyebabkan harga saham perusahaan yang meningkat juga.Hal ini didukung oleh penelitian (Iswajuni dkk., 2018), Mardiyati (2012) dan penelitian Chandra (2014) yang menyatakan bahwa profitabilitas berpengaruh positif dan signifikan terhadap nilai perusahaan. Sehingga hipotesis pada penelitian ini adalah:

H5 : Profitabilitas berpengaruh positif terhadap nilai perusahaan.

\section{METODE PENELITIAN}

Jenis penelitian ini adalah penelitian kausalitas dengan pendekatan kuantitatif. Tempat penelitian adalah Bursa Efek Indonesia. Unit analisis penelitian ini adalah laporan keuangan perusahaan-perusahaan dalam industri perbankan yang terdaftar di Bursa Efek Indonesia periode tahun 2014 - 2018 yang telah dipublikasikan. Populasi penelitian ini adalah perusahaan-perusahan dalam industri perbankan yang terdaftar di Bursa Efek Indonesia dan membuat serta mempublikasikan laporan keuangan tahun 2014 - 2018 yang berjumlah 41 perusahaan. Sampel pada penelitian ini diambil dengan kriteria-kriteria (purposive sampling) sebagai berikut :

a. Laporan Keuangan perusahaan perbankan yang dipublikasikan.

b. Perusahaan yang membagikan dividen dan yang tidak membagikan dividen.

c. Perusahaan yang memiliki kepemilikan manajerial.

d. Perusahaan yang memiliki kepemilikan institusional.

Adapun hasil seleksi sampel ditunjukkan pada Tabel 4.2

Tabel 2. Hasil Penentuan Sampel

\begin{tabular}{|l|c|}
\hline \multicolumn{1}{|c|}{ Kriteria } & Jumlah \\
\hline Perusahaan sektor perbankan yang terdaftar di BEI & 41 \\
\hline $\begin{array}{l}\text { Perusahaan dengan laporan keuangan tidak lengkap selama periode } \\
\text { penelitian 2016, 2017 dan 2018 }\end{array}$ & $(10)$ \\
\hline Jumlah sampel & 31 \\
\hline
\end{tabular}

Penelitian ini menggunakan data dokumentasi yang dikumpulkan melalui laporan tahunan perusahaan perbankan periode 2016-2018 yang terdapat di www.idx.co.id. Selain itu, digunakan pula www.e-bursa.com dan yahoo finance sebagai sumber pendukung penelitian. Jenis data penelitian ini adalah data sekunder perusahaan-perusahaan dalam industri perbankan yang terdaftar di Bursa Efek Indonesia tahun 2016 - 2018. Peneliti tidak menggunakan data periode 2014-2015 karena yang memenuhi kriteria dalam penelitian ini sangat sedikit sehingga jika data 2014-2015 diambil maka tidak dapat dilakukan pengolahan data panel karena diperiode tersebut kriteria variabel yang dibutuhkan tidak lengkap sehingga peneliti memutuskan untuk menggunakan periode 20162018 yang memenuhi syarat sesuai dengan purposive sampling.

Penelitian ini menggunakan kepemilikan institusional (INST/X $\left.{ }_{1}\right)$, kepemilikan manajerial (MANJ/X $\mathrm{X}_{2}$ ), Kebijakan Dividen $\left(\mathrm{DPR} / \mathrm{X}_{3}\right)$, Perilaku Oportunistik $\left(\mathrm{RISK} / \mathrm{X}_{4}\right)$ dan Profitabilitas $\left(\mathrm{ROA} / \mathrm{X}_{5}\right)$ sebagai variabel bebas (independent variable) untuk menentukan nilai perusahaan $(\mathrm{PBV} / \mathrm{Y})$ sebagai variabel terikat (dependent variable). Teknik analisis 
yang digunakan dalam penelitian ini yaitu menguji pengaruh variabel independen terhadap variabel dependen dengan software e-views dan menggunakan model regresi data panel yaitu gabungan antara data runtut waktu (time series) dan data silang (cross section).Metode estimasi model regresi dengan menggunakan data panel dapat dilakukan tiga pendekatan Basuki dan Yuliadi (2015), yaitu Common Effect Model, Fixed Effect Model dan Random Effect Model. Untuk memilih model yang paling tepat digunakan dalam mengelola data panel, terdapat beberapa pengujian yang dapat dilakukan yakni:

1. Uji Chow

Chow test yakni pengujian untuk menentukan model Fixed Effect atau Random Effect yang paling tepat digunakan dalam mengestimasi data panel.

2. Uji Hausman

Hausman test adalah pengujian statistik untuk memilih apakah model Fixed Effect atau Random Effect yang paling tepat digunakan.

3. Uji Lagrange Multiplier

Untuk mengetahui apakah model Random Effect lebih baik daripada metode Common Effect (OLS) digunakan uji Lagrange Multiplier (LM).

Adapun model Persamaan RegresiPanel adalah sebagai berikut:

$\mathrm{PBV}=\alpha+\beta_{1} \mathrm{KI}_{\text {it }}+\beta_{2} \mathrm{KM}_{\text {it }}+\beta_{3} \mathrm{DPR}_{\text {it }}+\beta_{4} \mathrm{Ri}_{\text {it }}+\beta_{5} \mathrm{ROA}_{\text {it }}+\mathrm{e}$

$\mathrm{PBV} \quad=$ Nilai Perusahaan (Variabel Dependen)

$b_{1-b_{5}}=$ Koefisien regresi masing- masing variabel independen

$\mathrm{KM}=$ Kepemilikan Manajer (Variabel Independen)

$\mathrm{KM}=$ Kepemilikan Instiusional (Variabel Independen)

DPR $=$ Kebijakan Dividen (Variabel Independen)

$R_{i} \quad=$ Risiko Pasar (Variabel Independen)

ROA $=$ Profitabilitas (Variabel Independen)

$\mathrm{e} \quad=$ Error term

$\mathrm{t} \quad=$ Waktu

Sebelum dilakukan pengujian hipotesis diuji asumsi klasik yang terdiri dari uji Multikolinieritas dan Uji Heteroskedsstisitas. Sedangkan pengujian hipotesis menggunakan Uji t, Uji F dan koefisien determinasi. Jika signifikan uji-t menunjukkan lebih kecil dari alpha 5\%, maka hipotesis penelitian diterima, sebaliknya, jika nilai signifikan uji-t menunjukkan lebih besar dari alpha 5\%, maka hipotesis peneltiian ditolak.

\section{HASIL DAN PEMBAHASAN}

Analisis Deskriptif

Tabel 3. Hasil Analisis Deskriptif

\begin{tabular}{|l|c|c|c|c|c|c|}
\hline & PBV & KI & KM & DPR & RI & ROA \\
\hline Mean & 2.942058 & 59.17366 & 8.134839 & 6.249449 & 0.733444 & 0.003713 \\
\hline Median & 0.977489 & 71.99000 & 0.010000 & 0.000000 & 0.037194 & 0.005872 \\
\hline Maximum & 130.7078 & 99.99000 & 77.79000 & 560.4128 & 13.88316 & 0.080784 \\
\hline Minimum & $2.62 \mathrm{E}-09$ & 0.000000 & 0.000000 & -0.211531 & -3.313734 & -0.117277 \\
\hline Std. Dev. & 13.92451 & 35.39233 & 20.54888 & 58.09179 & 2.168868 & 0.024191 \\
\hline Observations & 93 & 93 & 93 & 93 & 93 & 93 \\
\hline
\end{tabular}

Sumber : Data Sekunder diolah, 2020 
Analisis Deskriptif pada variabel Price to Book Value (PBV), memiliki nilai ratarata sebesar 2,942028 artinya dari 31 perusahaan perbankan di Bursa Efek Indonesia selama periode penelitian, kemampuan nilai buku saham dalam mempengaruhi kenaikan Harga Pasar Perlembar Saham adalah sebesar 2,94. Kepemilikan institusional (KI) diperoleh ratarata sebesar 59,17366 yang berarti rata -rata saham yang dimiliki oleh institusi adalah sebesar 59,17366 \%. Hasil deskriptif terhadap kepemilikan manajerial (KM) diperoleh ratarata sebesar 8,134839\% yang berarti rata -rata saham yang dimiliki oleh manajer (direksi, komisaris, manajer dan karyawan) adalah sebesar $8,13 \%$. Sedangkan rata-rata kebijakan dividen adalah sebesar 6,249449 yang berarti bahwa perusahaan perbankan memiliki kemampuan untuk membagikan dividen atas laba yang diperoleh sebesar 6,249\%. Perilaku opportunistik memiliki nilai rata-rata sebesar 0,7334 artinya dari 31 perusahaan perbankan selama periode penelitian, memiliki risiko sistematis sebesar 0,7334 yang berarti setiap peningkatan atau penurunan return market sebesar 1 point akan menyebabkan peningkatan dan penurunan harga saham sebesar 0,7334 point. Deskriptif terhadap variabel profitabilitas yang diukur dengan Return On Asset (ROA), menunjukkan bahwa rata-rata sebesar $0,003713 \%$ artinya dari 93observasi pada 31perusahaan perbankan selama periode penelitian, rata - rata nilai keuntungan perusahaan adalah sebesar $0,37 \%$ dari total aktiva yang dimiliki perusahaan.

\section{Hasil Analisis Regresi Panel}

Hasil uji persyaratan Regresi yaitu uji asumsi klasik menunjukkan bahwa data regresi tidak menunjukkan adanya multikolinieritas dengan VIF kurang dari 10 dan tidak terjadi heteroskedastisitas nilai probabilitas $p$-value $>0,05$. Sedangkan dalam pemilihan model regresi Panel dengan Uji Chow, Uji Hausman dan Uji LM ditemukan bahwa model Common Effect merupakan model regresi yang terbaik. Hasil pengujian terhadap model regresi panel dengan model Commont Effect yang menjelaskan kepemilikan institusioanal,kepemilikan manajemen, kebijakana deviden, perilaku oportunistik dan profitabilitas terhadap nilai perusahaan pada industri Perbankan periode tahun 2016 - 2018 dapat dilihat dalam tabel 4.3

Tabel 4. Hasil Analisis Regresi Common Effect

\begin{tabular}{|c|c|c|c|c|}
\hline Variabel & Koefisien regresi & $\mathbf{t}-$ hitung & Probability & Kesimpulan \\
\hline KI & 0.027146 & 5.783231 & 0.0000 & Signifikan \\
\hline KM & 0.001583 & 0.252353 & 0.8014 & Tidak Signifikan \\
\hline DPR & -0.006408 & -15.91683 & 0.0000 & Signifikan \\
\hline RI & 0.132596 & 1.140159 & 0.2573 & Tidak Signifikan \\
\hline ROA & 60.96931 & 8.775428 & 0.0000 & Signifikan \\
\hline C & 0.183072 & 0.906673 & 0.3671 & \\
\hline Adj. R Square & 0.870537 & & & \\
\hline F hitung & 124.7252 & & & \\
\hline Probability & 0,000 & & & \\
\hline
\end{tabular}

Sumber : Data Sekunder diolah, 2020

Persamaan model regresinya adalah

$$
\mathrm{PBV}=0,183+0,027 \mathrm{KI}+0.0015 \mathrm{KM}-0,0064 \mathrm{DPR}+0,1325 \mathrm{RI}+60,969 \mathrm{ROA}
$$


Nilai koefisien determinasi sebesar 0,8705, maka dapat diartikan bahwa 87,05\% Nilai perusahaan dapat dijelaskan oleh kelima variabel bebas yang terdiri kepemilikan institusioanal, kepemilikan manajemen, kebijakana deviden, perilaku oportunistik dan profitabilitas. Sedangkan sisanya sebesar $12,95 \%$ dipengaruhi oleh variabel lain yang tidak dimasukkan dalam model penelitian. Berdasarkan tabel 3 di atas, di dapat $\mathrm{F}$ hitung sebesar 124,725 dengan probabilitas sebesar 0,000 yang nilainya lebih kecil dari 0,05 maka Ha diterima dan menolak Ho (hipotesis ditolak). Ini menunjukkan bahwa model regresi telah memenuhi goodness of fit, sehingga dapat dinyatakan bahwa secara serentak kepemilikan institusioanal, kepemilikan manajemen, kebijakana deviden, perilaku oportunistik dan profitabilitas secara serentak berpengaruh secara signifikan terhadap nilai perusahaan.

\section{PEMBAHASAN \\ Pengaruh Kepemilikan Institusional terhadap Nilai perusahaan}

Hasil pengujian hipotesis pertama menemukan bahwa rasio kepemilikan institusional berpengaruh secara signifikan positif terhadap nilai perusahaan, dibuktikan dengan nilai $t_{\text {hitung }}$ sebesar 5,783, dan probabilitas sebesar 0,0000 yang nilainya jauh lebih kecil dari taraf signifikansi 0,05 . Hal ini berarti semakin tinggi kepemilikan institusional maka semakin tinggi pula nilai perusahaan. Hasil penelitian ini mendukung dengan penelitian Sualehkhattak dan Hussain ( 2017), Xiong (2016), Tandean dan Winnie (2016) , (Kurniaty dkk.,2018) yang menyatakan bahwa kepemilikan institusional berpengaruh positif terhadap nilai perusahaan

Kepemilikan saham oleh investor institusional dapat secara signifikan meningkatkan nilai perusahaan karena investor institusional akan aktif berpartisipasi dalam pengawasan dan pengelolaan operasi bisnis harian perusahaan, untuk mengendalikan perilaku agen operator dan mengurangi risiko masalah agen. Semakin tinggi proporsi kepemilikan saham investor institusional, semakin dekat hubungannya antara nilai perusahaan (Xiong, 2016). Semakin besar kepemilikan institusional maka semakin efisien pemanfaatan aktiva perusahaan dan diharapkan juga dapat bertindak sebagai pencegahan terhadap pemborosan dan manipulasi laba yang dilakukan oleh manajemen sehingga akan meningkatkan nilai perusahaan. Permanasari (2010) menyatakan bahwa tingginya kepemilikan institusi akan meningkatkan pengawasan terhadap perusahaan. Pengawasan yang tinggi ini kemungkinan akan meminimalisasi tingkat penyelewengan-penyelewengan yang dilakukan oleh pihak manajer.

\section{Pengaruh Kepemilikan Manajerial terhadap Nilai perusahaan}

Hasil pengujian hipotesis kedua menemukan bahwa rasio kepemilikan manajerial tidak berpengaruh signifikan positif terhadap nilai perusahaan, yang dibuktikan dengan nilai $t_{\text {hitung }}$ sebesar 0,2523 , dan probabilitas sebesar 0,8014 yang nilainya jauh lebih besar dari taraf signifikansi 0,05 . Hal ini berarti besar kecilnya kepemilikan manajerial belum berdampak terhadap peningkatan pula nilai perusahaan. Hasil penelitian ini mendukung dengan penelitian Warapsari dan Suaryana (2016) yang menemukan bahwa kepemilikan manajerial tidak berpengaruh signfiikan terhadap nilai perusahaan.

Hasil penelitian ini bertolak belakang dengan agency theory (Jensen \& Meckling, 1976), yang menyatakan bahwa semakin tinggi struktur kepemilikan oleh pihak insider (manajemen) maka semakin berkurang agency problem karena semakin selarasnya kepentingan antara manajer dan pemilik yang sebagian besar adalah manajemen sendiri 
sehingga dapat meningkatkan nilai perusahaan. Hasil penelitian ini mendukung penelitian yang dilakukan oleh Hardiningsih (2009) dan Abukosim et. al. (2014) yang menyimpulkan bahwa kepemilikan manajerial tidak berpengaruh terhadap nilai perusahaan. Temuan ini terkait dengan karakteristik perusahaan-perusahaan publik di Indonesia secara rata-rata memiliki proporsi kepemilikan saham manajerial yang relatif rendah. Dengan kepemilikan saham manajemen yang rendah, membuat manajemen hanya merupakan kepanjangan tangan dari pemilik mayoritas karena segala keputusan berada di pemegang saham mayoritas, sehingga dapat dikatakan keberadaan manajemen kurang memiliki pengaruh dalam kinerja keuangan perusahaan. Selain itu dengan rendahnya jumlah kepemilikan saham manajemen juga tidak dapat menyelaraskan kepentingan pemegang saham dan manajemen, menyebabkan manajemen kurang maksimal dalam menjalankan tugasnya untuk memaksimalkan kekayaan pemegang saham yaitu meningkatkan kinerja keuangan perusahaan. Hasil penelitian ini juga sejalan dengan penelitian yang dilakukan oleh Astuti (2014), dan Chilin (2007).

\section{Pengaruh Kebijakan Dividen terhadap Nilai perusahaan}

Hasil pengujian hipotesis ketiga menemukan bahwa kebijakan dividen justru berpengaruh secara signifikan negatif terhadap nilai perusahaan, yang dibuktikan dengan nilai $t_{\text {hitung }}$ sebesar $-15,916$, dan probabilitas sebesar 0,0000 yang nilainya jauh lebih kecil dari taraf signifikansi 0,05 . Hal ini berarti semakin besar kebijakan dividen maka semakin rendah nilai perusahaan. Hasil penelitian ini mendukung dengan penelitian Martha dkk (2018) dan penelitian Mayasari (2015) yang menemukan bahwa kebijakan dividen berpengaruh negatif signifikan terhadap nilai perusahaan.

Hasil dari penelitian ini berlawanan dengan prediksi yang menyatakan bahwa kebijakan dividen berpengaruh signifikan dan positif terhadap nilai perusahaan. Penelitian ini membuktikan semakin besar jumlah dividen yang dibagikan kepada perusahaan maka akan dapat menurunkan nilai dari sebuah perusahaan. Hal ini sesuai dengan teori Clientele Effect (Sjahrial, 2007), yang menyatakan bahwa ada sekelompok pemegang saham tidak begitu membutuhkan uang saat ini dan lebih suka apabila perusahaan menahan sebagian dari laba perusahaan, yang dapat meningkatkan saldo laba perusahaan. Saldo laba perusahaan yang tinggi maka akan memberikan peluang perusahaan untuk melakukan ekspansi (perluasan perusahaan), sehingga dapat menarik investor untuk membeli saham perusahaan. Jika banyak investor yang membeli saham perusahaan, maka permintaan saham perusahaan menjadi meningkat. Teori permintaan menyatakan semakin tinggi permintaan, semakin tinggi harganya. Jika harga saham meningkat maka nilai perusahaan juga meningkat. Karena peningkatan nilai perusahaan tercermin dari harga saham perusahaan tersebut.

\section{Pengaruh Opportunistic Behavior terhadap Nilai perusahaan}

Hasil pengujian hipotesis keempat menemukan bahwa Opportunistic Behavior tidak berpengaruh secara signifikan negatif terhadap nilai perusahaan, yang dibuktikan dengan nilai $t_{\text {hitung }}$ sebesar 1,14015 , dan probabilitas sebesar 0,2573 yang nilainya jauh lebih besar dari taraf signifikansi 0,05 . Kondisi ini dapat diartikan bahwa, perusahaan tidak dapat ditentukan oleh Opportunistic Behavior.Makna dari hasil tersebut adalah bahwa harga saham sebagai indikator dari nilai perusahaan tidak dipengaruhi oleh risiko sistematis atau Perilaku opportunistik. Beta saham sebagai indikator dari risiko sistematis menunjukkan 
tingkat volatilitas perubahan return pasar (IHSG) terhadap return saham. Oleh karena itu, semakin tinggi tingkat volatilitas perubahan return pasar (IHSG) terhadap return saham, semakin tinggi risiko perusahaan. Namun demikian risiko yang tinggi biasanya akan diikitu dengan keuntungan yang tinggi pula. Hal ini dapat dilihat dari rata-rata risiko sistematis yang hanya sebear 0,73 menunjukkan bahwa risiko ini belum mampu memberikan dampak negatif terhadap penurunan nilai perusahaan bahkan menunjukkan stabilitas harga yang baik. Risiko sistematis belum memiliki pengaruh terhadap nilai perusahaan, dalam konteks ini lebih diarahkan pada upaya meningkatkan kepercayaan masyarakat terhadap perusahaan dengan cara mempertahankan stabilitas laba yang berkelanjutan agar harga pasar sahamnya tetap stabil. Stabilitas harga saham penting, karena stabilitas ini akan menentukan indeks harga saham secara keseluruhan, dengan harga pasar saham yang stabil, maka indeks harga saham gabungan juga relatif stabil. Risiko sistematis rendah, kondisi ini akan menarik para pelaku bursa, karena dengan risiko sistematis yang rendah, maka stabilitas harga saham perusahaan perbankan akan lebih terjaga, sehingga belum mampu menurunkan nilai perusahaan.

\section{Pengaruh Profitabilitas terhadap Nilai perusahaan}

Hasil pengujian hipotesis pertama menemukan bahwa profitabilitas berpengaruh positif secara signifikan terhadap nilai perusahaan, yang dibuktikan dengan nilai $t_{\text {hitung }}$ sebesar 8,7754, dan probabilitas sebesar 0,0000 yang nilainya lebih kecil dari taraf signifikansi 0,05 . Hasil penelitian ini sesuai dengan penelitian penelitian yang dilakukan oleh Iswajuni dkk., 2018),(Purbawangsa dkk.,2019) Mardiyati (2012) dan penelitian Chandra (2014) yang menyatakan bahwa profitabilitas berpengaruh positif dan signifikan terhadap nilai perusahaan. Hal ini dikarenakan kontribusi peningkatan laba dapat memberikan indikasi bagi pemegang saham bahwa tingkat pengembalian investasi makin tinggi dan gambaran prospek perusahaan yang semakin baik karena adanya potensi peningkatan keuntungan atas jumlah modal yang disediakan oleh pemilik perusahaan. Perusahaan yang memperoleh laba tinggi merupakan perusahaan yang banyak dicari dan diminati oleh investor dikarenakan perusahaan yang memperoleh laba yang tinggi dinilai oleh investor memiliki prospek yang baik dimasa yang akan datang dan memberikan indikasi kemampuan perusahaan dalam pengelolaan perusahaan, sehingga dapat memicu investor untuk membeli saham perusahaan dan saham perusahaan menjadi meningkat. Permintaan saham yang meningkat akan menyebabkan harga saham perusahaan yang meningkat juga.

\section{KESIMPULAN}

Hasil penelitian menunjukkan bahwa Kepemilikan institusional dan profitabilitas berpengaruh positif secara signifikan terhadap nilai perusahaan. Sementara Kebijakan dividen berpengaruh negatif secara signifikan terhadap nilai perusahaan. Hasil yang lain menemukan bahwa Kepemilikan manajerial dan Perilaku oportunistik tidak berpengaruh positif secara signifikan terhadap nilai perusahaan. Implikasi hasil penelitian ini diharapkan bisa memberikan masukan dalam pembuatan keputusan investasi dan kredit. Sebaiknya investor mempertimbangkan kinerja keuangan perusahaan melalui rasio profitabilitas, dan kebijakan dividen karena terbukti berpengaruh signifikan terhadap nilai perusahaan. Sebaiknya investor memilih perusahaan yang memiliki rasio profitabilitas yang besar pada perusahaan perbankan yang dipilih namun membagikan dividen yang kecil karena karakter 
perusahaan ini kedepan akan menghasilkan harga saham yang lebih besar. Selain itu investor hendaknya memperhatikan besar kecilnya kepemilikan institusional perusahaan dengan memilih investasi yaitu perusahaan yang memiliki kepemilikan institusional yang tinggi, karena karakteristik perusahaan ini akan mampu mengontrol kinerja manajer sehingga mampu menaikkan nilai perusahaan.

Bagi peneliti yang akan datang, dengan memperhatikan keterbatasan yang ada, diharapkan penelitian selanjutnya dapat mempertimbangkan faktor-faktor sebagai berikut: Jumlah pengamatan yang digunakan dalam penelitian yang akan datang, tidak hanya sebatas pada perusahaan Perbankan yang listed di BEI dengan menggunakan periode yang lebih panjang, sehingga perusahaan yang menjadi sampel penelitian menjadi lebih banyak dan lebih representative. Hal ini dimaksudkan agar hasilnya bisa digeneralisir sebagai prediktor yang mempengaruhi nilai perusahaan. Bagi peneliti yang akan datang hendaknya menambahkan variabel-variabel lain yang diprediksikan mampu meningkatkan nilai perusahaan misalnya variabel GCG, pengungkapan sosial, likuiditas, atau variabel lainnya.

\section{DAFTAR PUSTAKA}

Azhari dan Ruzikna.2018."Pengaruh Kebijakan Dividen, Kebijakan Hutang Dan Profitabilitas Terhadap Nilai Perusahaan Manufaktur Sektor Pertambangan Yang Terdaftar Di Bursa Efek Indonesia Periode 2009-2014”. JOM FISIP Vol. 5 No. 1April 2018.

Candra Pami H. 2014. Pengaruh Profitabilitas, Kebijakan Deviden, Kebijakan Hutang, Keputusan Investasi dan Kepemilikan Insider Terhadap Nilai Perusahaan. Jurnal ilmu dan riset akuntansi. No.3 Vol.4. STIESIA Surabaya.

Fajarwati, Alni Rahmawati dan Fauziyah (2015). Statistika Teori dan Praktek. Yogyakarta : Bagian Penerbitan Manajemen Informatika UMY.

Florackis, C., Kanas, A., \& Kostakis, A. (2015). Dividend policy, managerial ownership and debt financing: A non-parametric perspective. European Journal of Operational Research, 241(3), 783-795.

Giriati. 2016. "Free Cash Flow, Dividend Policy, Investment Opportunity Set, Opportunistic Behavior and Firm's Value (A Study about Agency Theory)". Procedia - Social and Behavioral Sciences. Vol. 219, Hlm: 248-254.

Ghalandari, K. (2013). The Moderating Effects of Growth Opportunities on the Relationship between Capital Structure and Dividend Policy and Ownership Structure with Firm Value in Iran: Case Study of Tehran Securities Exchange. Research Journal of Applied Sciences, Engineering and Technology, 5(4), 1424-1431.

Hanafi, Mamduh M. dan Abdul Halim, 2014, Analisis Laporan Keuangan., Edisi tujuh., UPP AMP YKPN, Yogyakarta.

Handriani, Eka dan Robiyanto. 2018. Corporate Finance and Value in The Indonesian Manufacturing Companies. Jurnal Business Studies Vol. 11 No. 2.

Hani, S. (2015). Analisis Laporan Keuangan. Medan: Umsu Press

Herawati, T. (2013). Pengaruh Kebijakan Dividen, Kebijakan Hutang Dan Profitabilitas Terhadap Nilai Perusahaan. Jurnal Manajemen, 2(02).

Hidayah, Nurul. 2015. "Pengaruh Investment Opportunity Set (IOS) dan Kepemilikan Manajerial terhadap Nilai Perusahaan pada Perusahaan Property dan Real Estat di Bursa Efek Indonesia”. Jurnal Akuntansi. Vol. XIX, No. 03, Hlm: 420-432. 
Isshaq, Z; G. A. Bokpin, J. M. Onumah. 2009. Corporate Governance, Ownership Structure, Cash Holdings, and Firm Value on The Ghana Stock Exchange. The Journal of Risk Finance. 10(5): 488 - 499.

Iswajuni, I., Manasikana, A., \& Soetedjo, S. (2018). The effect of enterprise risk management (ERM) on firm value in manufacturing companies listed on Indonesian Stock Exchange year 2010-2013. Asian Journal of Accounting Research, 3(2), 224235.

Jensen, M. and Meckling, W. (1976). "Theory of the firm: managerial behavior, agency costs and ownership structure', Journal of Financial Economics, Vol. 3, pp. 305-60.

Jensen, Michael. C. 1986. "Agency Costs of Free Cash Flow, Corporate Finance, and Takeovers". American Economic Review. Vol. 76, Hlm: 323-329.

Juhandi, Nendi. 2013. The Effects of Internal Factors and Stock Ownership Structure on Dividend Policy on Company's Value [A Study on Manufacturing Companies Listed on the Indonesia Stock Exchange (IDX)]. International Journal of Business and Management Invention, 2 (11), pp: 6-18.

Kurniaty, S., Handayani, S. R., \& Rahayu, S. M. (2018). Stock return and financial performance as moderation variable in influence of good corporate governance towards corporate value. Asian Journal of Accounting Research

Mai, M. U. (2010). Dampak Kebijakan Dividen terhadap Nilai Perusahaan dalam Kajian Perilaku Oportunistik Manajerial dan Struktur Corporate Governance Studi Empiris pada Perusahaan Manufaktur Go Public di Pasar Modal Indonesia(Doctoral dissertation, Universitas Diponegoro).

Mardiyati, U., G. N. Ahmad., dan R. Putri. (2012). Pengaruh Kebijakan Dividen, Kebijakan Hutang, dan Profitabilitas terhadap Nilai Perusahaan yang Terdaftar di Bursa Efek Indonesia. Jurnal Riset Manajemen Sains Indonesia (JRMSI). 3(1): 1- 17.

Morck, R., Shleifer, A. and Vishny, R.W. (1988), "Management ownership and market valuation: an empirical analysis", Journal of Financial Economics, Vol. 20, pp. 293315.

Nguyen, T. T. N., \& Bui, P. K. (2019). Dividend policy and earnings quality in Vietnam. Journal of Asian Business and Economic Studies.

Nuraeni, Y., \& Haryanto, R. (2012). Pengaruh Manajemen Laba, Risiko Pasar Dan Struktur Kepemilikan Terhadap Nilai Pasar. Jurnal Ekonomi Dan Bisnis, 11(2), 137148.

Nurhayati, M. (2013). Profitabilitas, Likuiditas dan Ukuran Perusahaan Pengaruhnya Terhadap Kebijakan Dividen dan Nilai Perusahaan Sektor Non Jasa. Jurnal keuangan dan bisnis, 5(2), 144-153.

Permanasari, Wien Ika. 2010. Pengaruh Kepemilikan Manajerial, Kepemilikan Institusional, dan Corpotate Social Responsibility Terhadap Nilai Perusahaan. Skripsi. Fakultas Ekonomi Universitas Diponegoro.

Sukirni, Dwi. 2012. "Kepemilikan Manajerial, Kepemilikan Institusional, Kebijakan Dividen, dan Kebijakan Hutang Analisis terhadap Nilai Perusahaan". Accounting Analysis Journal. Vol. 1, No. 2.

Sualehkhattak, M., \& Hussain, C. M. (2017). "Do Growth Opportunities Influence the Relationship of Capital Structure, Dividend Policy and Ownership Structure with Firm Value: Empirical Evidence of KSE. ." J Account Mark, 6(1). 21689601.1000216 
Sugiarto, M. (2011). Pengaruh Struktur Kepemillkan dan Kebijakan Dividen Terhadap Nilai Perusahaan dengan Kebijakan Hutang Sebagai Intervening. Jurnal Akuntansi Kontemporer, 3(1).

Sharma, R. K., \& Bakshi, A. (2019). An evident prescience of determinants of dividend policy of Indian real estate companies. Journal of Financial Management of Property and Construction.

Tariq, H., Shahzad, F., Anwar, A., \& Rehman, I. U. (2019). Economic Consequences of Insider-ownership: An Emerging Market Perspective. In Asia-Pacific Contemporary Finance and Development (pp. 117-139). Emerald Publishing Limited.

Vintila, Georgeta dan Stefan Cristian Gherghina. "Does Corporate Governance Influences Corporate Financial Performance? Empirical Evidences for The Companies Listed on US Markets". International Business Research ISSN 1913-9004 E-ISSN 1913-9012. 2015, Vol. 8, No. 8.

Wibowo, Alexander Joseph Ibnu. 2013. Perilaku Oportunistik dalam Hubungan Kemitraan (Partnership): Sebuah Analisis Konseptual dengan Menggunakan Model IGMOB”. Bina Ekonomi Majalah Ilmiah Fakultas Ekonomi Unpar. Vol. 17, No. 2, Hlm: 86108.

Xiong, J. (2016). Institutional Investors, Dividend Policy and Firm Value-Evidence from China. Open Journal of Social Sciences, 4(08), 120.

Yulianti, Liza., 2014, "Pengaruh Keputusan Keuangan Dan Struktur Kepemilikan Terhadap Nilai Perusahaan (Studi Empiris Pada Perusahaan Manufaktur yang Terdaftar Di Bursa EfekIndonesia (BEI) Periode 2007 - 2011)”. Universitas Muhammadiyah Surakarta. 